\title{
Recent advances in understanding amyotrophic lateral sclerosis and emerging therapies
}

\author{
Lauren M. Gittings ${ }^{1}$ Rita Sattler ${ }^{1 *}$
}

${ }^{1}$ Department of Neurobiology, Barrow Neurological Institute, Phoenix, AZ, USA

\begin{abstract}
Amyotrophic lateral sclerosis (ALS) is a fatal neurodegenerative disease that is characterized by degeneration of both upper and lower motor neurons and subsequent progressive loss of muscle function. Within the last decade, significant progress has been made in the understanding of the etiology and pathobiology of the disease; however, treatment options remain limited and only two drugs, which exert a modest effect on survival, are approved for ALS treatment in the US. Therefore, the search for effective ALS therapies continues, and over 60 clinical trials are in progress for patients with ALS and other therapeutics are at the preclinical stage of development. Recent advances in understanding the genetics, pathology, and molecular mechanisms of ALS have led to the identification of novel targets and strategies that are being used in emerging ALS therapeutic interventions. Here, we review the current status and mechanisms of action of a selection of emerging ALS therapies in pre-clinical or early clinical development, including gene therapy, immunotherapy, and strategies that target neuroinflammation, phase separation, and protein clearance.
\end{abstract}

\section{Keywords}

ALS, Amyotrophic lateral sclerosis, ALS therapeutics, clinical trials, gene therapy, immunotherapy, platform trials

\section{Peer Review}

The peer reviewers who approve this article are:

1. Ludo van den Bosch, Center for Brain \& Disease Research (VIB) and Laboratory of Neurobiology (KU Leuven), Leuven, Belgium

Competing interests: No competing interests were disclosed.

2. James Shorter, Department of Biochemistry and Biophysics, Perelman School of Medicine, University of Pennsylvania, Philadelphia, PA, USA

Competing interests: No competing interests were disclosed. 
*Corresponding author: Rita Sattler (rita.sattler@dignityhealth.org)

Competing interests: The authors declare that they have no competing interests.

Grant information: This work was supported by the Barrow Neurological Foundation (RS).

The funders had no role in study design, data collection and analysis, decision to publish, or preparation of the manuscript.

Copyright: (C) 2020 Sattler R et al. This is an open access article distributed under the terms of the Creative Commons Attribution License, which permits unrestricted use, distribution, and reproduction in any medium, provided the original work is properly cited.

How to cite this article: Gittings LM and Sattler R. Recent advances in understanding amyotrophic lateral sclerosis and emerging therapies. Faculty Reviews 2020 9:(12) https://doi.org/10.12703/b/9-12

Published: 17 Nov 2020, Faculty Reviews 9:(12) https://doi.org/10.12703/b/9-12 


\section{Introduction}

Amyotrophic lateral sclerosis (ALS) is a fatal neurodegenerative disease characterized by progressive loss of upper motor neurons in the motor cortex and lower motor neurons in the brainstem and anterior horn of the spinal cord. Clinically, this manifests as weakness and atrophy of voluntary muscles, resulting in the loss of the ability to walk, speak, and swallow as the disease progresses ${ }^{1}$. Additionally, it is estimated that 20 to $50 \%$ of patients with ALS present with cognitive impairments that would meet the diagnostic criteria for probable or definite frontotemporal dementia (FTD) ${ }^{2}$. Disease prognosis is poor; most patients with ALS die within 3 to 5 years after the diagnosis; this is typically due to respiratory failure resulting from the progressive weakening of respiratory muscles ${ }^{1}$. Pathologically, more than $97 \%$ of ALS cases are characterized by inclusions of the nuclear RNA-binding protein (RBP) TAR DNA-binding protein 43 (TDP-43) in the cytoplasm of neurons and glia. The few cases that do not exhibit TDP-43 pathology present with pathological inclusions of either the superoxide dismutase (SOD1) or fused in sarcoma (FUS) protein ${ }^{3}$.

ALS can be broadly separated into two categories-familial ALS (fALS) (10-15\%) and sporadic ALS (sALS) (85-90\%)depending on whether there is a family history of $\mathrm{ALS}^{4}$. At least 50 potential causative or disease-modifying genes have been linked to $\mathrm{ALS}^{5}$, but a $\mathrm{G}_{4} \mathrm{C}_{2}$ hexanucleotide repeat expansion in the C9orf72 gene is the most common ALS-causing mutation identified to date, accounting for about $40 \%$ of fALS cases and 6 to $8 \%$ of sALS cases in Caucasian populations ${ }^{6}$. Other commonly mutated genes in ALS include SOD1, TARDPB, or FUS, and variants in other disease-causing ALS-linked genes are relatively uncommon ${ }^{4,7}$. ALS linked to mutations in these genes is hypothesized to be caused by loss-of-function or toxic gain-of-function of the protein products of these genes and subsequent downstream cellular consequences ${ }^{8}$. In contrast, three non-mutually exclusive mechanisms have been proposed as a potential cause of C9orf72-linked ALS: loss-of-function of the $C 9$ orf72 protein, sequestration of essential RBPs by foci containing $\mathrm{G}_{4} \mathrm{C}_{2}$-containing RNA, and toxicity induced by one or more dipeptide repeat (DPR) proteins ${ }^{9,10}$. These DPR proteins are produced as a result of bidirectional repeat-associated non-AUG initiated (RAN) translation of the $\mathrm{G}_{4} \mathrm{C}_{2}$ hexanucleotide repeat expansion and accumulate in p62-positive, TDP-43-negative pathological aggregates in C9orf72 repeat expansion carriers ${ }^{11-13}$.

Although research into genetic forms of ALS has implicated several dysregulated biological pathways in ALS pathogenesis, the precise mechanism of disease is unknown. The lack of a defined cause of disease is reflected in the number of currently available therapeutics for ALS. Despite many previous and ongoing clinical trials of various drugs targeting different biological mechanisms (comprehensively reviewed in 14 and 15), only two approved treatments are currently in widespread use for ALS: the anti-excitotoxic drug riluzole and edaravone, whose mechanism of action is unknown but presumed to be through its antioxidant properties ${ }^{16,17}$.
Here, we present a collection of emerging therapeutic approaches based on a selection of recent novel pre-clinical discoveries covering a broad range of ALS disease mechanisms or genetics (or both). A summary of the therapeutic approaches that are discussed in this review and have entered clinical trials is provided in Table 1 .

\section{Gene therapies}

The heritability of fALS makes the disease a promising candidate for gene therapy; as such, clinical trials that use the principles of gene therapy are under way in fALS patients carrying SOD1 (NCT02623699) and C9orf72 (NCT03626012) mutations. Gene therapy is a broad term that can refer to reducing the expression of an RNA of the disease-causing gene, delivering a "normal" copy of a mutated gene to replace its expression, or modifying the mutant genome to "correct" a genetic defect ${ }^{18}$. All three of these genetic therapeutics have shown efficacy in experimental models, raising the possibility of successful gene therapy trials for fALS.

\section{Antisense oligonucleotides}

Antisense oligonucleotides (ASOs) are short (13-25 nucleotides), synthetic, and single-stranded oligonucleotides that are designed to bind to specific sequences of RNA to reduce, restore, or modify RNA or protein expression ${ }^{19}$. The oligonucleotides typically contain chemical modifications that act to enhance pharmacokinetic properties and target binding affinity and the tolerability profile of the ASOs ${ }^{20,21}$. Depending on their target, binding sequence, and chemistry, single-stranded ASOs can modulate gene expression or modify pre-mRNA splicing through several distinct mechanisms of action, including target degradation, translational arrest, inhibition of RBP binding, splicing modulation, and altering translational activity ${ }^{19,21}$. Although ASOs do not cross the blood-brain barrier, they are effectively distributed throughout the central nervous system (CNS) when delivered into cerebrospinal fluid and have demonstrated promising results in the treatment of other neurological diseases $^{22-24}$.

The first demonstration of a therapeutic potential in ALS was a 20-nucleotide ASO-targeting SOD1. Intra-cerebroventricular injections of this ASO in mutant SOD1 rats resulted in the reduction of SOD1 mRNA and protein levels throughout the brain and spinal cord and slowed disease progression ${ }^{25}$. This ASO strategy of targeting SOD1 has since been tested in patients with SOD1 ALS in clinical trials. Intrathecal administration of the ASO (BIIB067, tofersen) was found to be safe and well tolerated and caused a significant reduction in SOD1 protein levels in the CNS in addition to slowing clinical decline in patients with SOD1 $\mathrm{ALS}^{26}$. Following these promising results, the ASO is being tested in patients with SOD1 ALS in a multicenter phase III placebo-controlled trial (NCT02623699).

For C9orf72-linked FTD/ALS, several ASO molecules have been designed and their beneficial effects have been demonstrated in numerous C9orf72 cellular and animal models, including C9orf72 patient induced pluripotent stem cell (iPSC)-derived 


\begin{tabular}{|c|c|c|c|c|c|c|}
\hline Therapeutic & $\begin{array}{l}\text { Therapeutic } \\
\text { approach }\end{array}$ & Therapeutic target & Class of drug & $\begin{array}{l}\text { Eligible ALS } \\
\text { population }\end{array}$ & $\begin{array}{l}\text { Trial } \\
\text { phase }\end{array}$ & $\begin{array}{l}\text { ClinicalTrials.gov } \\
\text { Identifier }\end{array}$ \\
\hline $\begin{array}{l}\text { Tofersen } \\
\text { (BlIB067) }\end{array}$ & $\begin{array}{l}\text { Gene therapy: } \\
\text { antisense } \\
\text { oligonucleotide }\end{array}$ & SOD1 transcript & $\begin{array}{l}\text { Antisense } \\
\text { oligonucleotide }\end{array}$ & SOD1 ALS & III & NCT02623699 \\
\hline BIIB078 & $\begin{array}{l}\text { Gene therapy: } \\
\text { antisense } \\
\text { oligonucleotide }\end{array}$ & $\begin{array}{l}\text { C9orf72 repeat } \\
\text { expansion }\end{array}$ & $\begin{array}{l}\text { Antisense } \\
\text { oligonucleotide }\end{array}$ & C9orf72 ALS & I & NCT03626012 \\
\hline Masitinib & $\begin{array}{l}\text { Modulating } \\
\text { neuroinflammation }\end{array}$ & $\begin{array}{l}\text { Tyrosine kinase } \\
\text { inhibitor }\end{array}$ & Small molecule & $\begin{array}{l}\text { Familial or } \\
\text { sporadic ALS }\end{array}$ & III & NCT03127267 \\
\hline $\begin{array}{l}\text { Ibudilast } \\
\text { (MN-166) }\end{array}$ & $\begin{array}{l}\text { Modulating } \\
\text { neuroinflammation }\end{array}$ & $\begin{array}{l}\text { Phosphodiesterase } \\
\text { inhibitor }\end{array}$ & Small molecule & $\begin{array}{l}\text { Familial or } \\
\text { sporadic ALS }\end{array}$ & II / III & NCT04057898 \\
\hline Fasudil & $\begin{array}{l}\text { Modulating } \\
\text { neuroinflammation }\end{array}$ & Rho kinase inhibitor & Small molecule & Not specified & II & NCT03792490 \\
\hline Ravulizumab & $\begin{array}{l}\text { Modulating } \\
\text { neuroinflammation }\end{array}$ & $\begin{array}{l}\text { Complement } \\
\text { component } 5 \\
\text { inhibitor }\end{array}$ & $\begin{array}{l}\text { Monoclonal } \\
\text { antibody }\end{array}$ & $\begin{array}{l}\text { Familial or } \\
\text { sporadic ALS }\end{array}$ & III & NCT04248465 \\
\hline Zilucoplan & $\begin{array}{l}\text { Modulating } \\
\text { neuroinflammation }\end{array}$ & $\begin{array}{l}\text { Complement } \\
\text { component } 5 \\
\text { inhibitor }\end{array}$ & Small molecule & $\begin{array}{l}\text { Familial or } \\
\text { sporadic ALS }\end{array}$ & II / III & NCT04297683 \\
\hline Anakinra & $\begin{array}{l}\text { Modulating } \\
\text { neuroinflammation }\end{array}$ & $\begin{array}{l}\mathrm{IL}-1 \text { receptor } \\
\text { antagonist }\end{array}$ & $\begin{array}{l}\text { Monoclonal } \\
\text { antibody }\end{array}$ & $\begin{array}{l}\text { Familial or } \\
\text { sporadic ALS }\end{array}$ & II & NCT01277315 \\
\hline Tocilizumab & $\begin{array}{l}\text { Modulating } \\
\text { neuroinflammation }\end{array}$ & $\begin{array}{l}\mathrm{IL}-1 \text { receptor } \\
\text { antagonist }\end{array}$ & $\begin{array}{l}\text { Monoclonal } \\
\text { antibody }\end{array}$ & Not specified & II & NCT02469896 \\
\hline Arimoclomol & $\begin{array}{l}\text { Clearance } \\
\text { of protein } \\
\text { aggregates }\end{array}$ & $\begin{array}{l}\text { Upregulates heat } \\
\text { shock proteins }\end{array}$ & Small molecule & Not specified & III & NCT03491462 \\
\hline Colchicine & $\begin{array}{l}\text { Clearance } \\
\text { of protein } \\
\text { aggregates }\end{array}$ & $\begin{array}{l}\text { Enhances } \\
\text { expression of } \\
\text { HSPB8 }\end{array}$ & Small molecule & Sporadic ALS & II & NCT03693781 \\
\hline Rapamycin & $\begin{array}{l}\text { Clearance } \\
\text { of protein } \\
\text { aggregates }\end{array}$ & $\begin{array}{l}\text { Stimulate } \\
\text { autophagy }\end{array}$ & Small molecule & $\begin{array}{l}\text { Familial or } \\
\text { sporadic ALS }\end{array}$ & II & NCT03359538 \\
\hline $\begin{array}{l}\text { BIIB100/KPT- } \\
350\end{array}$ & $\begin{array}{l}\text { Targeting } \\
\text { nucleocytoplasmic } \\
\text { transport }\end{array}$ & $\begin{array}{l}\text { XPO1/CRM1 } \\
\text { inhibitor }\end{array}$ & Small molecule & Not specified & I & NCT03945279 \\
\hline $\begin{array}{l}\text { HEALEY } \\
\text { platform trial }\end{array}$ & Various & Various & Various & $\begin{array}{l}\text { Familial or } \\
\text { sporadic ALS }\end{array}$ & II / III & NCT04297683 \\
\hline
\end{tabular}

ALS, amyotrophic lateral sclerosis; IL-1, interleukin 1; SOD1, superoxide dismutase; XPO1, exportin 1.

neurons and C9orf72 BAC transgenic mouse models ${ }^{27-34}$. Following the success of C9orf72-targeting ASOs in pre-clinical models, a phase I clinical trial of the first ASO (BIIB078) targeting C9orf72 mRNA in C9orf72 ALS patients was initiated in September 2018 and is ongoing (NCT03626012).

In addition to directly targeting ALS-causing mutations, pre-clinical experiments have tested ASOs targeting mRNAs that encode disease-modifying proteins, such as ataxin-2. Intermediate numbers (22-33 repeats) of the poly-glutamine repeat in ATXN2 are associated with an increased risk of $\mathrm{ALS}^{35,36}$. Genetic knock-out or heterozygous deletion of ATXN2 homologs can rescue TDP-43 toxicity in yeast, Drosophila, and a
TDP-43 transgenic mouse, and a single administration of an ASO targeting ataxin-2 into the CNS of TDP-43 transgenic mice resulted in improved motor function and survival ${ }^{35,37}$. Given that accumulations of TDP-43 are by far the most common pathology seen in patients with ALS, these studies indicate that an ataxin-2-targeting ASO, if effective, has the potential to be therapeutically beneficial to large cohorts of patients with ALS, including patients with sALS.

\section{Adeno-associated viral vectors}

The use of viral vectors to deliver genetic material required for gene replacement or knock-down is another therapy being explored in the treatment of ALS. Currently, the most frequently 
used viral vectors for neurodegenerative and other diseases of the CNS are adeno-associated viral (AAV) vectors ${ }^{38}$. AAV recombinant vectors are non-enveloped, single-stranded DNA-containing viruses that are modified such that the viral genome contains the desired therapeutic gene to be delivered along with only the necessary endogenous viral genes required for packaging ${ }^{38}$. AAV9 is the principal serotype used for the development of therapeutics in neurological diseases, including ALS, because of its high transduction efficiency in neurons, ability to spread broadly throughout the CNS, and its ability to cross the blood-brain barrier, enabling intravenous delivery ${ }^{39}$. AAV vectors can be used to deliver a "normal" copy of a disease-causing gene or to deliver RNA interference (RNAi) molecules-including small interfering RNAs (siRNAs), short hairpin RNAs (shRNAs), and microRNAs (miRNAs) - to downregulate and degrade mRNA transcripts of the targeted gene $^{38}$.

Thus far, most ALS AAV vector therapies tested pre-clinically target mutant SOD1. Several groups have demonstrated the effective therapeutic potential of using AAV vectors to deliver miRNA or shRNA targeting mutant SOD1 in SOD1 ${ }^{\mathrm{G} 93 \mathrm{~A}}$ rat and mouse models ${ }^{40-44}$. These studies all successfully demonstrated that AAV vector treatment resulted in knock-down of mutant SOD1 mRNA or protein expression (or both), slowed disease progression, and extended life span; one more recent study reported an increased median survival of $50 \%{ }^{40}$. The safety and efficacy of intrathecal delivery of AAV vectors targeting mutant SOD1 have also been demonstrated in non-human primate models $^{41,44}$ and more recently in two familial ALS patients carrying SOD1 gene mutations ${ }^{45}$. Following these successes, an AAV9 viral vector containing an shRNA targeting mutant SOD1 (AVXS-301) is under pre-clinical development and is expected to be tested in patients with SOD1 ALS in a phase I clinical trial in the near future ${ }^{14}$. Although AAV gene therapy is moving forward for ALS caused by SOD1 mutations, it is important to note that SOD1 mutations account for a small percentage of ALS cases, and it remains to be seen whether this therapy would also be beneficial to patients with sALS, as has been previously proposed ${ }^{46}$.

Targeting the more common genetic cause of ALS, C9orf72, with an AAV vector would be of benefit to a larger cohort of patients with ALS. The principle of using AAV9-miRNA to silence the $C 90$ orf 72 transcript was successfully demonstrated in cultures of primary cortical neurons derived from $C 9$ orf 72 BAC transgenic mice ${ }^{47}$. In addition, a more recent study has shown that an AAV5 vector containing miRNAs targeting repeat-containing $C 9$ orf 72 transcripts was able to reduce the accumulation of repeat-containing $C 9$ orf 72 transcripts in both the nucleus and cytoplasm of iPSC-derived frontal brain-like neurons ${ }^{48}$. Furthermore, intra-striatal delivery of these AAV5-miRNAs into 90-day-old C9orf72 BAC transgenic mice lowered the expression of total and repeat-containing C9orf72 mRNA transcripts, although no behavioral changes were observed in the mice following treatment ${ }^{48}$. Although reducing the levels of C9orf72 transcripts has shown some promise in these experimental models, some concerns have been raised regarding the potential adverse effects caused by a reduction in the endogenous levels of the $\mathrm{C} 90 \mathrm{orf} 72$ protein, and a recent study demonstrated that reducing $\mathrm{C} 9$ orf 72 function in a mouse model exacerbated phenotypes induced by the presence of the $C 9$ orf72 repeat expansion ${ }^{49}$.

\section{CRISPR-Cas9 genome editing}

CRISPR-Cas9 genome editing technology has rapidly advanced within the last decade, making it a potential therapeutic option for human diseases arising from genetic mutations. This technology makes use of a naturally occurring prokaryotic defense mechanism to insert, modify, or remove specific sequences of DNA using a targeting guide RNA, a Cas9 DNA endonuclease, and the cells' natural DNA repair mechanisms ${ }^{50}$. In a therapeutic setting, these components would most likely be delivered via an AAV vector, adopting the principles learnt from AAV-mediated gene therapies ${ }^{51}$.

For ALS cases caused by the C9orf72 mutation, the most likely CRISPR-Cas9-mediated approach would be to remove the hexanucleotide repeat expansion sequence. As proof of concept, this approach has been used successfully to generate isogenic C9orf72 patient-derived iPSCs ${ }^{52-54}$. CRISPR-Cas9 excision of the repeat sequence reduces some of the pathological hallmarks of the diseases, including repeat RNA foci and DPR proteins. A recent study has also demonstrated that a similar reduction in DPR proteins and a rescue of neurodegeneration can be achieved by using CRISPR to selectively delete the C9orf72 promoter region ${ }^{55}$. However, before CRISPR-Cas9 technology may be of therapeutic use in C9orf72-linked ALS, it will be important to address the problem of potentially introducing insertion/deletion events into the wild-type allele, which may have functional consequences to the C9orf72 gene $^{56}$. Finally, a recent study successfully targeted the Cas 9 protein to the repeat RNA instead of the DNA in an attempt to circumvent permanent genomic changes ${ }^{57}$.

For SOD1 ALS, it may be possible to use CRISPR-Cas9 genome editing to correct specific disease-causing mutations, delete the mutant SOD1 gene, or introduce strategic mutations to disable the mutant SOD1 function. This approach has been successful in the SOD1 ${ }^{\mathrm{G} 93 \mathrm{~A}}$ mouse model where CRISPR/Cas9 editing in vivo reduced expression of mutant SOD1, delayed disease onset, and increased survival ${ }^{58,59}$. AAV-delivered CRISPR-Cas9 technology has also been tested in combination with a cytidine base editor to introduce a nonsense coding mutation into the mutant SOD1 gene to permanently disable SOD1 expression in the SOD1 ${ }^{\mathrm{G} 93 \mathrm{~A}}$ mouse model. This treatment slowed disease progression, prolonged survival, and caused $40 \%$ fewer SOD1 inclusions in end-stage mice compared with control $^{60}$.

Further in vitro and in vivo validation work is required to establish the feasibility and tolerability CRISPR-Cas9-mediated therapeutics in fALS as a number of challenges associated with genome editing technology—such as target specificity, off-target genome editing, and immunogenicity-would need to be overcome before it could be a viable therapeutic. Additionally, 
there would need to be significant ethical and regulatory changes put in place before this technology enters the clinic.

\section{Modulating neuroinflammation}

In addition to motor neuron death and muscle denervation, a characteristic feature of ALS pathology is neuroinflammation ${ }^{61,62}$. Increasing evidence from ALS patient tissue and animal studies has implicated activation of astrocytes, microglia, and the complement system, T-lymphocyte infiltration and production of inflammatory cytokines in ALS pathogenesis ${ }^{61-64}$. Furthermore, numerous in vitro studies of motor neurons co-cultured with astrocytes, microglia, or T cells derived from iPSCs carrying an ALS-causing mutation or ALS mouse models have demonstrated that these cells have a toxic effect on motor neurons ${ }^{46,65-69}$. Given the increased activation of the immune system in ALS, several clinical trials have investigated using various classes of anti-inflammatory drugs as an ALS therapeutic. Although many anti-inflammatory drugs have failed to demonstrate clinical efficacy, a number of trials remain ongoing and different aspects of the immune system are being targeted ${ }^{61,70}$.

Modulating aberrant activation of microglia is the target of many of the drugs currently in trials. Microglia are the resident immune cells of the CNS and are classically described to exist in two different states: resting and activated. Whereas resting microglia survey their microenvironment and perform crucial roles to maintain homeostasis, activated microglia react rapidly to environmental abnormalities and can be both protective and detrimental to the surrounding cellular environment, a phenomenon that is sometimes referred to as M1 or M2 phenotypes ${ }^{71}$. Microglia are considered to have a "toxic" phenotype when they are responsible for the release of proinflammatory cytokines and are now often referred to as diseaseassociated microglia ${ }^{72,73}$. At the same time, microglia show neuroprotective properties when they release anti-inflammatory cytokines and remove cellular debris by phagocytosis ${ }^{72}$. Aberrant activation and an imbalance of toxic and protective microglia states are thought to promote inflammation and motor neuron degeneration in ALS; thus, anti-inflammatory drugs that reduce microglia activation or induce a protective microglia phenotype are being explored as therapeutic options $\mathrm{s}^{61,71}$.

Masitinib is a tyrosine kinase inhibitor that reduces microglia proliferation and activation. It has shown promising results in both pre-clinical and clinical trials. Oral administration of masitinib decreased microgliosis, reduced motor neuron pathology, and prolonged post-paralysis survival in SOD1 ${ }^{\mathrm{G} 93 \mathrm{~A}}$ mice $^{74}$. When translated into a phase II/III trial (NCT02588677), masitinib in combination with riluzole demonstrated a slowed decline of the Revised ALS Functional Rating Scale (ALSFRS-R) in patients with "normal progressor" ALS" ${ }^{75}$ A further phase III (NCT03127267) trial of masitinib in combination with riluzole is due to commence shortly.

Ibudilast has also recently gained approval to be tested in a phase IIb/III trial (NCT04057898) in patients with ALS after a phase II trial demonstrated that the drug was safe and had potential benefits on survival ${ }^{76}$. Ibudilast is a small-molecule inhibitor of phosphodiesterase 4 and 10 and Toll-like receptor 4 and is thought to promote an anti-inflammatory effect. Interestingly, ibudilast has also been shown to significantly enhance the clearance of TDP-43 and SOD1 protein aggregates and protect against TDP-43-mediated toxicity in cell culture models, suggesting that this drug may exhibit more than anti-inflammatory properties $^{77}$.

Fasudil is another drug that acts to modulate microglia activation and phenotype. It is a Rho kinase (ROCK) inhibitor that reduces the release of pro-inflammatory cytokines and has been shown to promote expression of neuroprotective microglia markers upon stimulation in cellular models and significantly prolong survival and motor function by modulation of microglial activity in SOD1 ${ }^{\mathrm{G} 93 \mathrm{~A}}$ mice $^{78-80}$. Fasudil is being investigated in a phase IIa clinical trial (NCT03792490) in patients with early-stage $\mathrm{ALS}^{81}$. A recent case study of three patients who were granted compassionate treatment of fasudil before the trial began has reported that the drug was well tolerated; however, no conclusions with regard to drug efficacy could be drawn ${ }^{82}$. This will be assessed via several secondary endpoint measures in the ongoing phase IIa trial ${ }^{81}$.

In addition to targeting microglia, anti-inflammatory drugs that target the complement system are being tested in patients with ALS. The complement system is part of the innate immune system which acts to enhance the immune response. The system consists of several small proteins that circulate in the blood as inactive precursors which become activated by proteases upon stimulation by one of several triggers ${ }^{83}$. In ALS, there is increasing evidence of aberrant activation of various components of the complement system in the onset and progression of motor phenotypes ${ }^{83,84}$. The terminal protein of the complement system, complement component 5 (C5), has been identified as a potential therapeutic target in ALS on the basis of evidence of C5a receptor upregulation in post-mortem ALS tissue and SOD1 $1^{\mathrm{G} 93 \mathrm{~A}}$ animal models and the fact that pharmacological inhibition of the $\mathrm{C} 5 \mathrm{a}$ receptor improved symptoms and prolonged survival in $\mathrm{SOD}^{\mathrm{G} 93 \mathrm{~A}}$ mice ${ }^{85,86}$. Clinical trials in patients with ALS are planned for two drugs acting on C5. A phase III trial (NCT04248465) is under way in both sALS and fALS patients to test the efficacy and safety of ravulizumab, a humanized monoclonal antibody designed to bind to and inhibit the activation of C5. Similarly, a phase II trial (NCT04297683) in both sALS and fALS patients is planned for a synthetic peptide inhibitor of $\mathrm{C} 5$ activation, zilucoplan.

A third intervention targeting neuroinflammation in ALS is suppression of the effects of pro-inflammatory cytokines by antagonizing cytokine receptors. This is an effective strategy already used in the treatment of inflammatory diseases such as rheumatoid arthritis, and several of these anti-inflammatory drugs are being trialed for repurpose in ALS. Examples include the interleukin-1 (IL-1) receptor antagonist, anakinra (NCT01277315), and tocilizumab (NCT02469896), a monoclonal antibody targeting the IL-6 receptor. Pilot studies in a small number of patients 
with sALS indicate that anakinra and tocilizumab can lower cytokine levels and induce a down-regulation of inflammatory genes, respectively ${ }^{87,88}$.

\section{Immunotherapy}

Protein aggregates are a pathological hallmark of all cases of ALS regardless of disease etiology and include, but are not exclusive to, SOD1, FUS, TDP-43, but also C9orf72 repeat translated DPR proteins. In experimental models of several other neurodegenerative disorders, antibody-based therapies have been effective in reducing the cell-to-cell transmission of toxic proteins-such as tau, amyloid- $\beta$, and $\alpha$-synuclein-and removal of pathological aggregates of these proteins ${ }^{89,90}$. A similar immunotherapy approach has been explored to reduce protein aggregation in models of ALS. This either involves direct injection of a purified antibody into the target organism (passive immunity) or can involve a vaccination approach whereby the target organism is injected with a recombinant form of the toxic protein in order to stimulate in vivo antibody production against the target protein (active immunity).

For SOD1 ALS, several studies have demonstrated the benefits of both active and passive immunotherapy in mutant SOD1 models, although the success of injecting recombinant SOD1 mutant protein to induce immunity seems to be dependent on the SOD1 mutation. Although vaccination against SOD1 has been shown to delay disease onset, increase life span, and enhance the clearance of SOD1 aggregates in the SOD1 ${ }^{\mathrm{G} 37 \mathrm{R}} \operatorname{model}^{91-93}$, this immunization strategy has not been successful in extending life span in the SOD1 ${ }^{\mathrm{G} 93 \mathrm{~A}}$ mouse model, and some studies have reported a worsening of disease phenotype, likely due to adverse immune responses ${ }^{91,94,95}$. In contrast, studies that used a passive immunity approach by treating mutant SOD1 mouse models with various types of antibodies specific for misfolded SOD1 all reported delayed disease onset, increased life span, and a reduction in mutant SOD1 protein levels ${ }^{96-98}$.

In C9orf72-linked ALS, antibodies targeting DPR proteins, in particular poly-glycine-alanine (GA), have shown promising effects in experimental models. Antibodies raised against the poly-GA protein are able to reduce intracellular poly-GA aggregation in primary neuron cultures and blocked the seeding activity of brain lysates extracted from $C 9$ orf 72 patient brain ${ }^{99}$. Recent studies have further demonstrated beneficial effects of antiGA antibodies in two C9orf72 mouse models, as shown by reduced behavioral deficits, decreased neuroinflammation, and prolonged survival ${ }^{100}$, as well as reduced TDP-43 cytoplasmic mislocalization, suggesting that the immunotherapy was able to elicit effects downstream of poly-GA aggregation ${ }^{101}$. These studies support the concept that poly-GA immunotherapy could be a viable therapeutic approach in reducing some aspects of C9orf72-linked ALS; however, given the multi-factorial disease pathogenesis of $C 9 \circ r 72$, it is likely that treatment will require a synergistic approach when targeting downstream mechanisms.

Given that most ALS cases present with TDP-43 pathology, antibodies targeting this protein would be of therapeutic benefit to a larger population of patients with ALS, including sALS. Indeed, single-chain antibodies that recognize different regions of TDP-43 have been investigated as potential therapeutics ${ }^{102,103}$. In mutant TDP-43 transfected cell lines, an antibody targeting the nuclear export signal of TDP-43 was found to have high affinity for and accelerated proteasome-mediated degradation of aggregated TDP-43. Furthermore, following in utero electroporation in embryonic mouse brain, the antibody caused a marked reduction in the number and size of mutant TDP-43 aggregates ${ }^{102}$. Similarly, an antibody targeting the RNA recognition motif of TDP-43 significantly reduced TDP-43 proteinopathy, motor defects, and neuroinflammation in transgenic mice expressing ALS-linked TDP-43 mutations ${ }^{103}$. It is important to note that mutant TDP-43 was studied in both cases. Given that mutations in TDP-43 account for only 5\% of fALS cases, it will be important to assess whether antibody-based therapy is able to reduce aggregation of the wild-type protein, as this is the more common TDP-43 protein species found in ALS patients with TDP-43 proteinopathy.

\section{Stimulating clearance of protein aggregates}

An alternative therapeutic strategy aimed at the disassembly of protein aggregates is based on enhancing protein quality control systems via heat shock proteins. These proteins are essential to intracellular protein quality control and function as molecular chaperones to correctly fold, stabilize, and prevent the unwanted aggregation of proteins ${ }^{104}$. Arimoclomol, a compound that induces the upregulation of several heat shock proteins, has shown therapeutic benefit in the SOD $1^{\mathrm{G} 93 \mathrm{~A}}$ mouse model of $\mathrm{ALS}^{105}$. Administration of arimoclomol significantly improved muscle strength, motor neuron survival, and prolonged life span compared with controls when treated from the time of symptom onset ${ }^{106,107}$. Histopathological analysis of arimoclomol-treated mice revealed a reduction in the abundance of ubiquitin-positive aggregates in motor neurons compared with untreated mice, suggesting that arimoclomol was acting as an anti-aggregation drug in this model of $\mathrm{ALS}^{107}$. In patients with rapidly progressing SOD1 ALS, arimoclomol was found to be safe and well tolerated and provided therapeutic benefit across a range of efficacy outcome measures in a randomized, doubleblind, placebo-controlled trial ${ }^{108}$. A larger randomized phase 3 clinical trial to evaluate the efficacy and safety of arimoclomol in patients with sporadic and familial ALS is under way (NCT03491462). Whilst arimoclomol has demonstrated therapeutic benefit in SOD1 ALS, it will be particularly interesting to see the effect of arimoclomol on non-SOD1 ALS patients given that pre-clinical research on arimoclomol in non-SOD1 ALS is currently limited.

One molecular chaperone that is of particular interest with regard to ALS therapeutics is HSPB8. This protein has been shown to recognize and promote the autophagy-mediated removal of misfolded TDP-43 fragments, mutant SOD1, and C9orf72 DPR proteins $^{109-111}$. Furthermore, HSPB8 can form a chaperone complex with BAG3 and HSP70, the latter of which acts as a key regulator of stress granule surveillance to help prevent the conversion of dynamic stress granules into more solid aggregates ${ }^{112}$. HSPB8 in increasing levels is being explored as an ALS 
therapeutic in a phase II clinical trial of colchicine (NCT03693781), which is known to enhance the expression of HSPB8 and several other proteins involved in autophagy as well as exhibiting anti-inflammatory properties ${ }^{113}$.

An additional molecular chaperone of therapeutic interest is Hsp104, a heat shock protein with disaggregase activity that is naturally found in Saccharomyces cerevisiae, where it functions to regulate the construction and disassembly of yeast prion proteins $^{114,115}$. Interestingly, despite Hsp104 being conserved between bacteria and many eukaryotes, no homolog of Hsp104 exists within the animal kingdom, making it an attractive candidate as an exogenous therapeutic ${ }^{116,117}$. Although wild-type Hsp104 has only moderate effects on the disaggregation of human proteins associated with neurodegenerative diseases, variants of Hsp104 have been engineered to suppress TDP-43 and FUS aggregation and toxicity in yeast models ${ }^{118-120}$. Furthermore, co-expression of Hsp104 variants with ALS-linked mutant FUS in mammalian cells promoted the dissolution of FUS inclusions $^{121}$. Further investigation is required to determine whether Hsp104 variants have the same effect on TDP-43 aggregates in mammalian cells and whether this extends to in vivo ALS models. It will also be necessary to determine whether expression of Hsp104 in mammalian cells has any detrimental effects on the normal protein folding process before this can be pursued as a therapeutic ${ }^{15}$.

A less targeted approach to stimulating the disassembly of pathological protein aggregates would be to increase the activity of specific cellular protein quality control pathways. Several genes linked to ALS are known to play a role in autophagy, which has led to the suggestion that dysfunctional autophagy may influence disease pathogenesis and thus therapeutic strategies aimed at enhancing autophagy could be an effective treatment for the disease. Several studies have demonstrated that stimulating autophagy can enhance the clearance of mutant SOD1, TDP-43, or FUS in vitro; however, results in in vivo models have been mixed ${ }^{122-128}$. Despite these conflicting pre-clinical studies, a placebo-controlled phase 2 clinical trial to assess the biological and clinical effect of the potent autophagy-inducing drug rapamycin is ongoing in patients with ALS (NCT03359538).

\section{Targeting phase separation}

In addition to stimulating the disassembly of protein aggregates, another therapeutic strategy could be to prevent the initial formation of these structures by interfering with the process of liquid-liquid phase separation (LLPS). This is a naturally occurring phenomenon that underlies the formation of various membrane-less organelles, such as the nucleolus and stress granules, and occurs when proteins demix from an aqueous solution and form dynamic liquid-like droplets. This process is believed to be mediated by low-complexity domains within the phase-separating protein, a property that is common among many of the RBPs implicated in ALS, including TDP-43, FUS, and hnRNPA $1^{129-131}$. While LLPS is essential to maintain cellular function, recent in vitro and cellular studies have demonstrated that liquid-like droplets are capable of solidifying over time, resulting in the formation of insoluble aggregates, which can have toxic consequences for the cell ${ }^{132,133}$. Given that many of aggregated proteins detected in patients with ALS are capable of this phenomenon, a therapeutic strategy being explored in pre-clinical experiments is interfering with LLPS to prevent the deleterious process of liquid-like droplets, particularly stress granules, from forming insoluble aggregates. Although no clinical translation of these studies is planned at present, these preclinical experiments demonstrate how an understanding of the basic biology and biochemistry of the disease can lead to the emergence of novel therapeutic strategies.

The use of RNA bait oligonucleotides is one strategy being explored after a study demonstrated that binding of RNA to TDP-43 suppresses LLPS and inclusion formation in a lightinducible model of TDP-43 LLPS ${ }^{134}$. Treatment of cortical-like neuronal cells with a bait RNA oligonucleotide that exhibited high affinity for the RNA recognition motif of TDP-43 suppressed phase transition of TDP-43 and reduced neurotoxicity in a dose-dependent manner. The use of such RNA oligonucleotides could be a viable therapeutic treatment as they could be readily administered to patients in a similar manner to the ASO therapies currently being trialed. Another therapeutic option targeting phase separation would be using small molecules. A number of studies have identified compounds that show antiTDP-43 aggregation properties ${ }^{135-137}$. A recent small-molecule screen identified several planar compounds capable of modulating stress granule size, number, and dynamics and preventing the accumulation of TDP-43 within persistent cytoplasmic puncta in mutant TDP-43 iPSC-derived motor neurons ${ }^{138}$. Although both strategies are effective in reducing the deleterious accumulation of TDP-43, caution must be taken with this strategy not to interfere with the normal physiological function of phase separation and formation of essential membrane-less organelles.

Targeting post-translational modifications (PTMs) of phaseseparating proteins may also be a therapeutic strategy as some modifications have been found to influence the aggregation propensity of ALS-linked proteins. Poly(ADP-ribosyl)ation is an important PTM in the regulation of stress granule dynamics, and it was recently discovered that TDP-43 and hnRNPA1 are targets of poly(ADP-ribose) polymerases (PARPs) ${ }^{139,140}$. The addition of poly(ADP-ribose) units to these proteins enhances their phase separation, while PARP inhibition is able to reduce accumulation of cytoplasmic TDP-43 foci and rescue TDP-43associated neurotoxicity in NSC-34 cells, rat primary spinal cord neurons, and Drosophila models of ALS ${ }^{139-141}$. These studies suggest that inhibition of PARPs could be an effective strategy to regulate aberrant phase separation in ALS, and given that PARP inhibitors are already safely used clinically for the treatment of various cancers, this could be a viable therapeutic option $^{142}$. Arginine methylation is another PTM known to regulate the phase separation of the ALS-linked protein FUS. The addition of methyl groups to arginine residues within FUS by protein arginine methyltransferase (PRMT) enzymes reduces the ability of FUS to phase-separate and form hydrogels in vitro ${ }^{143,144}$. Treatment with select concentrations of a global methyltransferase inhibitor has been shown to mitigate the cytoplasmic mislocalization and aggregation of mutant FUS in a cell culture 
system $^{145}$. However, caution is warranted with increasing PRMT activity as these enzymes target a large number of essential proteins that would likely be affected by this treatment. However, the discovery that PTMs can have a profound effect on the behavior of aggregation-prone proteins opens up the possibility of therapeutically manipulating a range of different enzymes to reduce the aberrant phase separation of aggregation-prone proteins. Thus, PTMs of ALS-associated proteins should be further explored to uncover potential therapeutic targets.

\section{Targeting nucleocytoplasmic transport}

Deficits in nucleocytoplasmic transport have been widely reported in several models of ALS as well as other neurodegenerative disorders ${ }^{146}$. The most common defect seen in ALS patients with TDP-43 pathology is the depletion of TDP-43 from the nucleus, resulting in loss of essential nuclear functions of the RBP. In a healthy neuron, TDP-43 can rapidly traffic between the nucleus and cytoplasm; however, pathological depletion of TDP-43 from the nucleus is toxic to neurons, both in vitro and in vivo ${ }^{147,148}$. A similar phenomenon is observed in patients with ALS-FUS, where the predominantly nuclear FUS protein is mislocalized from the nucleus to the cytoplasm ${ }^{149}$. Thus, preventing the nuclear export or enhancing nuclear import of these proteins has been investigated as a therapeutic strategy for ALS.

TDP-43 contains a canonical nuclear export signal (NES) that is predicted to be recognized by the nuclear export factor exportin 1 (XPO1/CRM1), a nuclear export pathway that can be inhibited by selective inhibitors of nuclear export (SINE) compounds. Inhibition of XPO1 by SINE compounds has been shown to reduce TDP-43-induced cortical neuron death, rescue larval locomotor defects, and partially restore motor function in a TDP-43 overexpressing rat model ${ }^{150,151}$. Additionally, genetic knockdown of XPO1 in a Drosophila can rescue disease phenotypes associated with FUS or $\mathrm{G}_{4} \mathrm{C}_{2}$ repeat-induced neurotoxicity ${ }^{33,152}$. Interestingly, treatment with SINE compounds or siRNA depletion of nuclear export proteins had limited effects on the nuclear localization of TDP-43 in rat primary cortical neurons at concentrations shown to rescue TDP-43induced toxicity ${ }^{150}$. This observation is in line with recent studies that have suggested that the NES of TDP-43 is not functional and most TDP-43 export from the nucleus is likely a result of passive diffusion ${ }^{153,154}$. Therefore, it appears that the protective effects of SINEs may be mediated through other unknown mechanisms that are independent of TDP-43 localization. Despite currently lacking a clear mechanism of action, a small-molecule inhibitor of XPO1, BIIB100/KPT-350, is being tested in a placebo-controlled phase 1 clinical trial in patients with ALS (NCT03945279).

Recently, it has been shown that select nuclear import receptors are capable of antagonizing aberrant phase separation and stimulating the disassembly of protein aggregates. Several groups have demonstrated that, in addition to its nuclear import function, karyopherin $\beta 2$ /transportin 1 functions as a molecular chaperone to prevent FUS aggregation by interfering with its ability to phase-separate and can disassemble preformed fibrils and hydrogels of FUS in vitro ${ }^{143,144,155-157}$. Overexpression of karyopherin $\beta 2$ also reduced toxicity in both human cells expressing mutant FUS and mutant FUS Drosophila models ${ }^{155}$. Additionally, karyopherin $\beta 2$ has been shown to inhibit and reverse the fibrillization of several other RBPs linked to ALS/FTD, including TAF15, EWSR1, hnRNPA1, and hnRNAP2 ${ }^{155}$. Although this strategy is far from any clinical use, the utilization of nuclear importers as an antagonist for aberrant phase separation demonstrates the innovative potential of therapeutic strategies that have emerged from recent advances in our understanding of ALS biology.

\section{Emergence of new clinical trial design for ALS therapies}

The search for effective ALS therapies is not only dependent on advances in understanding disease biology and the emergence of novel targets, it is also reliant on well-designed and executed clinical trials. The majority of ALS clinical trials to date have followed the often costly and time-consuming, traditional randomized clinical trial design of testing a single treatment in a homogenous group of patients. As it has become clear that ALS is a multi-faceted and heterogeneous disease, at both the clinical and molecular levels, a need for a new trial design is warranted. Trials for other diseases, particularly cancers, have benefitted from the use of a "platform trial" design ${ }^{158-161}$. A platform trial is a clinical trial with a single master protocol in which multiple treatments are evaluated simultaneously across one or more types of patients and allows for further additions or exclusions of new therapies or patient populations during the trial ${ }^{158,162}$. This model accelerates the development of therapies by rapidly evaluating the effectiveness of multiple therapies simultaneously, increasing patient access, and lowering the cost of trials. Furthermore, data from all patients receiving a placebo in each group can be combined, enhancing the statistical power of the trial. In January 2020, the US Food and Drug Administration granted approval for the first platform trial in patients with ALS. Initially, the HEALEY ALS platform trial (NCT04297683) will involve simultaneously trialing three potential therapeutic drugs, and new treatments and additional participants will be added as they become available. This trial design is estimated to decrease the trial time by $50 \%$, increase patient participation by $67 \%$, and reduce the cost of research by $30 \%^{163}$. It is hoped that use of the platform trial model will help accelerate the development of effective ALS therapies.

\section{Summary}

It is clear from the number of identified therapeutic targets discussed here that ALS is a complex and heterogeneous disease for which the development of therapies has been a challenging process. Nevertheless, significant progress made within the last few years has increased understanding of the genetics, pathology, and mechanisms of disease and led to the emergence of a range of novel therapeutic strategies, many of which are now entering clinical trials. As ALS research advances, it is becoming clear that the different forms of ALS exhibit unique molecular characteristics and pathologies-for example, DPR proteins in C9orf72-ALS and FUS aggregates in FUS-ALS-yet they all share common motor neuron neurodegeneration and 
inflammatory features that make them clinically indistinguishable. These similarities and differences have given rise to the development of therapeutic strategies that are highly specific, targeted to a discrete pathological mechanism, as well as strategies that affect features common to all patients with ALS. As understanding of ALS pathobiology increases, it is becoming more unlikely that a single therapeutic will prove to be effective in treating all forms of ALS caused by different underlying molecular differences. Instead, a more appropriate approach may be to use a combination of synergistic therapeutics to target different aspects of disease pathogenesis. However, therapies that target common features of the disease, such as inflammation and protein aggregate clearance, could prove to be useful adjunct therapies that modify disease progression. To complement this approach, the introduction of a platform trial design to ALS trials will hopefully accelerate the search to find effective therapies as it allows fast assessment of multiple therapeutic strategies. As many of the therapies discussed here enter or continue through clinical trials within the next few years, it will become clearer which therapeutic strategies, or potential combinations, are likely to make the most significant impact on disease outcomes.

\section{Acknowledgments}

The authors thank Lynette Bustos and Stephen Moore, from the Department of Neurobiology, Barrow Neurological Institute, for feedback and comments during manuscript preparation.
1. Brown RH, Al-Chalabi A: Amyotrophic Lateral Sclerosis. N Engl J Med. 2017; 377(2): 162-172

PubMed Abstract | Publisher Full Text

2. Ringholz GM, Appel SH, Bradshaw M, et al:: Prevalence and patterns of cognitive impairment in sporadic ALS. Neurology. 2005; 65(4): 586-90.

PubMed Abstract | Publisher Full Text

3. Ling SC, Polymenidou M, Cleveland DW: Converging mechanisms in ALS and FTD: Disrupted RNA and protein homeostasis. Neuron. 2013; 79(3): 416-38. PubMed Abstract | Publisher Full Text | Free Full Text

4. Mathis S, Goizet C, Soulages A, et al.: Genetics of amyotrophic lateral sclerosis: A review. J Neurol Sci. 2019; 399: 217-226. PubMed Abstract | Publisher Full Text

5. Boylan K: Familial Amyotrophic Lateral Sclerosis. Neurol Clin. 2015; 33(4) 807-30.

PubMed Abstract | Publisher Full Text | Free Full Text

6. Majounie E, Renton AE, Mok K, et al.: Frequency of the C9orf72 hexanucleotide repeat expansion in patients with amyotrophic lateral sclerosis and frontotemporal dementia: A cross-sectional study. Lancet Neurol. 2012; 11(4): 323-30.

PubMed Abstract | Publisher Full Text | Free Full Text

Faculty Opinions Recommendation

7. Chia R, Chiò A, Traynor BJ: Novel genes associated with amyotrophic lateral sclerosis: Diagnostic and clinical implications. Lancet Neurol. 2018; 17(1) 94-102.

PubMed Abstract | Publisher Full Text | Free Full Text

8. Taylor JP, Brown RH Jr, Cleveland DW: Decoding ALS: From genes to mechanism. Nature. 2016; 539(7628): 197-206. PubMed Abstract | Publisher Full Text | Free Full Text

9. Balendra R, Isaacs AM: C9orf72-mediated ALS and FTD:Multiple pathways to disease. Nat Rev Neurol. 2018; 14(9): 544-58.

PubMed Abstract | Publisher Full Text | Free Full Text

10. Gendron TF, Petrucelli L: Disease Mechanisms of C9ORF72 Repeat Expansions. Cold Spring Harb Perspect Med. 2018; 8(4): a024224. PubMed Abstract | Publisher Full Text | Free Full Text

11. Ash PEA, Bieniek KF, Gendron TF, et al.: Unconventional translation of C9ORF72 GGGGCC expansion generates insoluble polypeptides specific to c9FTD/ALS. Neuron. 2013; 77(4): 639-46. PubMed Abstract | Publisher Full Text | Free Full Text | Faculty Opinions Recommendation

12. Gendron TF, Bieniek KF, Zhang YJ, et al:: Antisense transcripts of the expanded C9ORF72 hexanucleotide repeat form nuclear RNA foci and undergo repeatassociated non-ATG translation in c9FTD/ALS. Acta Neuropathol. 2013; 126(6) 829-44.

PubMed Abstract | Publisher Full Text | Free Full Text

13. Mori K, Weng SM, Arzberger T, et al:: The C9orf72 GGGGCC repeat is translated into aggregating dipeptide-repeat proteins in FTLD/ALS. Science. 2013;
339(6125): 1335-8

PubMed Abstract | Publisher Full Text

14. Chiò A, Mazzini L, Mora G: Disease-modifying therapies in amyotrophic lateral sclerosis. Neuropharmacology. 2020; 167: 107986 PubMed Abstract | Publisher Full Text

15. Wobst HJ, Mack KL, Brown DG, et al.: The clinical trial landscape in amyotrophic lateral sclerosis-Past, present, and future. Med Res Rev. 2020 40(4): 1352-84.

PubMed Abstract | Publisher Full Text | Free Full Text |

Faculty Opinions Recommendation

16. Miller RG, Mitchell JD, Moore DH, et al.: Riluzole for amyotrophic lateral sclerosis (ALS)/motor neuron disease (MND). Cochrane Database Syst Rev. 2012; (2): CD001447.

PubMed Abstract | Publisher Full Text

17. Abe K, Itoyama $\mathrm{Y}$, Sobue G, et al:: Confirmatory double-blind, parallel-group placebo-controlled study of efficacy and safety of edaravone (MCl-186) in amyotrophic lateral sclerosis patients. Amyotroph Lateral Scler Frontotemporal Degener. 2014; 15(7-8): 610-7.

PubMed Abstract | Publisher Full Text | Free Full Text

18. Cappella M, Ciotti C, Cohen-Tannoudji M, et al:: Gene Therapy for ALS-A Perspective. Int J Mol Sci. 2019; 20(18): 4388.

PubMed Abstract | Publisher Full Text | Free Full Text

19. Rinaldi C, Wood MJA: Antisense oligonucleotides: The next frontier for treatment of neurological disorders. Nat Rev Neurol. 2018; 14(1): 9-21. PubMed Abstract | Publisher Full Text

20. Sharma VK, Sharma RK, Singh SK: Antisense oligonucleotides: Modifications and clinical trials. Medchemcomm. 2014; 5: 1454-71. Publisher Full Text

21. Evers MM, Toonen LJA, van Roon-Mom WMC: Antisense oligonucleotides in therapy for neurodegenerative disorders. Adv Drug Deliv Rev. 2015; 87: 90-103. PubMed Abstract | Publisher Full Text

22. Leavitt BR, Tabrizi SJ: Antisense oligonucleotides for neurodegeneration. Science. 2020; 367(6485): 1428-1429. PubMed Abstract | Publisher Full Text

23. Tabrizi SJ, Leavitt BR, Landwehrmeyer GB, et al:: Targeting Huntingtin Expression in Patients with Huntington's Disease. N Engl J Med. 2019; 380(14): 2307-2316.

PubMed Abstract | Publisher Full Text | Faculty Opinions Recommendation

24. Finkel RS, Mercuri E, Darras BT, et al:: Nusinersen versus Sham Control in Infantile-Onset Spinal Muscular Atrophy. N Engl J Med. 2017; 377(18): 1723-32. PubMed Abstract | Publisher Full Text | Faculty Opinions Recommendation

25. Smith RA, Miller TM, Yamanaka K, et al:: Antisense oligonucleotide therapy for neurodegenerative disease. J Clin Invest. 2006; 116(8): 2290-6. PubMed Abstract | Publisher Full Text | Free Full Text

26. Miller TM, Pestronk A, David W, et al.: An antisense oligonucleotide against 
SOD1 delivered intrathecally for patients with SOD1 familial amyotrophic lateral sclerosis: A phase 1,randomised, first-in-man study. Lancet Neurol. 2013; 12(5): 435-42.

PubMed Abstract | Publisher Full Text | Free Full Text

Faculty Opinions Recommendation

27. Donnelly CJ, Zhang PW, Pham JT, et al:: RNA toxicity from the ALS/FTD C9ORF72 expansion is mitigated by antisense intervention. Neuron. 2013; 80(2): 415-28.

PubMed Abstract | Publisher Full Text | Free Full Text

28. Lagier-Tourenne C, Baughn M, Rigo F, et al:: Targeted degradation of sense and antisense C9orf72 RNA foci as therapy for ALS and frontotemporal degeneration. Proc Natl Acad SciU S A. 2013; 110(47): E4530-9. PubMed Abstract | Publisher Full Text | Free Full Text

29. O'Rourke JG, Bogdanik L, Muhammad AKMG, et al: C9orf72 BAC Transgenic Mice Display Typical Pathologic Features of ALS/FTD. Neuron. 2015; 88(5): 892-901. PubMed Abstract | Publisher Full Text | Free Full Text

30. Sareen D, O'Rourke JG, Meera P, et al.: Targeting RNA foci in iPSC-derived motor neurons from ALS patients with a C9ORF72 repeat expansion. Sci Transl Med. 2013; 5(208): 208ra149.

PubMed Abstract | Publisher Full Text | Free Full Text

31. Jiang J, Zhu Q, Gendron TF, et al:: Gain of Toxicity from ALS/FTD-Linked Repeat Expansions in C9ORF72 Is Alleviated by Antisense Oligonucleotides Targeting GGGGCC-Containing RNAs. Neuron. 2016; 90(3): 535-50. PubMed Abstract | Publisher Full Text | Free Full Text

32. Gendron TF, Chew J, Stankowski JN, et al:: Poly(GP) proteins are a useful pharmacodynamic marker for C9ORF72-associated amyotrophic lateral sclerosis. Sci Transl Med. 2017; 9(383): eaai7866. PubMed Abstract | Publisher Full Text | Free Full Text Faculty Opinions Recommendation

33. Zhang K, Donnelly CJ, Haeusler AR, et al.: The C9orf72 repeat expansion disrupts nucleocytoplasmic transport. Nature. 2015; 525(7567): 56-61. PubMed Abstract | Publisher Full Text | Free Full Text Faculty Opinions Recommendation

34. Hu J, Liu J, Li L, et al.: Engineering Duplex RNAs for Challenging Targets: Recognition of GGGGCC/CCCCGG Repeats at the ALS/FTD C9orf72 Locus. Chem Biol. 2015; 22(11): 1505-11.

PubMed Abstract | Publisher Full Text | Free Full Text

35. Elden AC, Kim HJ, Hart MP, et al.: Ataxin-2 intermediate-length polyglutamine expansions are associated with increased risk for ALS. Nature. 2010; 466(7310): 1069-75.

PubMed Abstract | Publisher Full Text | Free Full Text | Faculty Opinions Recommendation

36. C Lee T, Li YR, Ingre C, et al:: Ataxin-2 intermediate-length polyglutamine expansions in European ALS patients. Hum Mol Genet. 2011; 20(9): 1697-700. PubMed Abstract | Publisher Full Text | Free Full Text | Faculty Opinions Recommendation

37. Becker LA, Huang B, Bieri G, et al.: Therapeutic reduction of ataxin-2 extends lifespan and reduces pathology in TDP-43 mice. Nature. 2017; 544(7650): 367-71.

PubMed Abstract | Publisher Full Text | Free Full Text

38. Choudhury SR, Hudry E, Maguire CA, et al:: Viral vectors for therapy of neurologic diseases. Neuropharmacology. 2017; 120: 63-80. PubMed Abstract | Publisher Full Text | Free Full Text

39. Deverman BE, Ravina BM, Bankiewicz KS, et al.: Gene therapy for neurological disorders: Progress and prospects. Nat Rev Drug Discov. 2018; 17(10): 767. PubMed Abstract | Publisher Full Text

40. Stoica L, Todeasa SH, Cabrera GT, et al:: Adeno-associated virus-delivered artificial microRNA extends survival and delays paralysis in an amyotrophic lateral sclerosis mouse model. Ann Neurol. 2016; 79(4): 687-700. PubMed Abstract | Publisher Full Text | Free Full Text

41. Borel F, Gernoux G, Cardozo B, et al.: Therapeutic rAAVrh10 Mediated SOD1 Silencing in Adult SOD1 ${ }^{\mathrm{G} 93 \mathrm{~A}}$ Mice and Nonhuman Primates. Hum Gene Ther 2016; 27(1): 19-31.

PubMed Abstract | Publisher Full Text | Free Full Text

42. Wang H, Yang B, Qiu L, et al.: Widespread spinal cord transduction by intrathecal injection of rAAV delivers efficacious RNAi therapy for amyotrophic lateral sclerosis. Hum Mol Genet. 2014; 23(3): 668-81. PubMed Abstract | Publisher Full Text | Free Full Text

43. Thomsen GM, Gowing G, Latter J, et al.: Delayed disease onset and extended survival in the SOD ${ }^{\text {G93A }}$ rat model of amyotrophic lateral sclerosis after suppression of mutant SOD1 in the motor cortex. J Neurosci. 2014; 34(47): $15587-600$.

PubMed Abstract | Publisher Full Text | Free Full Text

44. Foust KD, Salazar DL, Likhite S, et al:: Therapeutic AAV9-mediated suppression of mutant SOD1 slows disease progression and extends survival in models of inherited ALS. Mol Ther 2013; 21(12): 2148-59. PubMed Abstract | Publisher Full Text | Free Full Text

45. Mueller C, Berry JD, McKenna-Yasek DM, et al.: SOD1 Suppression with
Adeno-Associated Virus and MicroRNA in Familial ALS. N Engl J Med. 2020;

383(2): 151-8

PubMed Abstract | Publisher Full Text

46. Haidet-Phillips AM, Hester ME, Miranda CJ, et al:: Astrocytes from familial and sporadic ALS patients are toxic to motor neurons. Nat Biotechnol. 2011; 29(9): 824-8.

PubMed Abstract | Publisher Full Text | Free Full Text

47. Peters OM, Cabrera GT, Tran H, et al:: Human C9ORF72 Hexanucleotide Expansion Reproduces RNA Foci and Dipeptide Repeat Proteins but Not Neurodegeneration in BAC Transgenic Mice. Neuron. 2015; 88(5): 902-909. PubMed Abstract | Publisher Full Text | Free Full Text

48. Martier R, Liefhebber JM, García-Osta A, et al.: Targeting RNA-Mediated Toxicity in C9orf72 ALS and/or FTD by RNAi-Based Gene Therapy. Mol Ther Nucleic Acids. 2019; 16: 26-37.

PubMed Abstract | Publisher Full Text | Free Full Text | Faculty Opinions Recommendation

49. Z Zhu Q, Jiang J, Gendron TF, et al:: Reduced C9ORF72 function exacerbates gain of toxicity from ALS/FTD-causing repeat expansion in C9orf72. Nat Neurosci. 2020; 23(5): 615-24.

PubMed Abstract | Publisher Full Text | Free Full Text |

Faculty Opinions Recommendation

50. Adli M: The CRISPR tool kit for genome editing and beyond. Nat Commun 2018; 9(1): 1911.

PubMed Abstract | Publisher Full Text | Free Full Text | Faculty Opinions Recommendation

51. Wang D, Zhang F, Gao G: CRISPR-Based Therapeutic Genome Editing: Strategies and In Vivo Delivery by AAV Vectors. Cell. 2020; 181(1): 136-50. PubMed Abstract | Publisher Full Text | Free Full Text

52. Selvaraj BT, Livesey MR, Zhao C, et al.: C9ORF72 repeat expansion causes vulnerability of motor neurons to $\mathrm{Ca}^{2+}$-permeable AMPA receptor-mediated excitotoxicity. Nat Commun. 2018; 9(1): 347.

PubMed Abstract | Publisher Full Text | Free Full Text

53. Lopez-Gonzalez R, Yang D, Pribadi M, et al:: Partial inhibition of the overactivated Ku80-dependent DNA repair pathway rescues neurodegeneration in C9ORF72-ALS/FTD. Proc Natl Acad Sci U S A. 2019; 116(19): 9628-33.

PubMed Abstract | Publisher Full Text | Free Full Text

54. Andrade NS, Ramic M, Esanov R, et al:: Dipeptide repeat proteins inhibit homology-directed DNA double strand break repair in C9ORF72 ALS/FTD. Mol Neurodegener. 2020; 15(1): 13.

PubMed Abstract | Publisher Full Text | Free Full Text

55. Krishnan G, Zhang Y, Gu Y, et al.: CRISPR deletion of the C9ORF72 promoter in ALS/FTD patient motor neurons abolishes production of dipeptide repeat proteins and rescues neurodegeneration. Acta Neuropathol. 2020; 140(1): 81-4.

PubMed Abstract | Publisher Full Text | Free Full Text |

Faculty Opinions Recommendation

56. Schaefer KA, Wu WH, Colgan DF, et al:: Unexpected mutations after CRISPRCas9 editing in vivo. Nat Methods. 2017; 14(6): 547-8. PubMed Abstract | Publisher Full Text | Free Full Tex

57. Batra R, Nelles DA, Pirie E, et al:: Elimination of Toxic Microsatellite Repeat Expansion RNA by RNA-Targeting Cas9. Cell. 2017; 170(5): 899-912.e10. PubMed Abstract | Publisher Full Text | Free Full Text | Faculty Opinions Recommendation

58. Gaj T, Ojala DS, Ekman FK, et al.: In vivo genome editing improves motor function and extends survival in a mouse model of ALS. Sci Adv. 2017; 3(12): eaar3952.

PubMed Abstract | Publisher Full Text | Free Full Text

59. Duan W, Guo M, Yi L, et al:: The deletion of mutant SOD1 via CRISPR/Cas9/ sgRNA prolongs survival in an amyotrophic lateral sclerosis mouse model. Gene Ther. 2020; 27(3-4): 157-69. PubMed Abstract | Publisher Full Text

60. Lim CKW, Gapinske M, Brooks AK, et al:: Treatment of a Mouse Model of ALS by In Vivo Base Editing. Mol Ther. 2020; 28(4): 1177-89. PubMed Abstract | Publisher Full Text | Free Full Text

61. Liu J, Wang F: Role of Neuroinflammation in Amyotrophic Lateral Sclerosis: Cellular Mechanisms and Therapeutic Implications. Front Immunol. 2017; 8: 1005.

PubMed Abstract | Publisher Full Text | Free Full Text

62. McCauley ME, Baloh RH: Inflammation in ALS/FTD pathogenesis. Acta Neuropathol. 2019; 137(5): 715-30. PubMed Abstract | Publisher Full Text | Free Full Text

63. Brettschneider J, Toledo JB, van Deerlin VM, et al.: Microglial activation correlates with disease progression and upper motor neuron clinical symptoms in amyotrophic lateral sclerosis. PLoS One. 2012; 7(6): e39216. PubMed Abstract | Publisher Full Text | Free Full Text

64. Kawamata $\mathrm{T}$, Akiyama $\mathrm{H}$, Yamada $\mathrm{T}$, et al:: Immunologic reactions in 
amyotrophic lateral sclerosis brain and spinal cord tissue. Am J Pathol. 1992; 140(3): 691-707.

PubMed Abstract | Free Full Text

65. Frakes AE, Ferraiuolo L, Haidet-Phillips AM, et al.: Microglia induce motor neuron death via the classical NF-KB pathway in amyotrophic lateral sclerosis. Neuron. 2014; 81(5): 1009-23.

PubMed Abstract | Publisher Full Text | Free Full Text

66. Coque E, Salsac C, Espinosa-Carrasco G, et al.: Cytotoxic CD8 ${ }^{+} \mathbf{T}$ lymphocytes expressing ALS-causing SOD1 mutant selectively trigger death of spinal motoneurons. Proc Natl Acad Sci U S A. 2019; 116(6): 2312-7. PubMed Abstract | Publisher Full Text | Free Full Text | Faculty Opinions Recommendation

67. Nagai M, Re DB, Nagata T, et al:: Astrocytes expressing ALS-linked mutated SOD1 release factors selectively toxic to motor neurons. Nat Neurosci. 2007 10(5): 615-22.

PubMed Abstract | Publisher Full Text | Free Full Text

68. Hall CE, Yao Z, Choi M, et al.: Progressive Motor Neuron Pathology and the Role of Astrocytes in a Human Stem Cell Model of VCP-Related ALS. Cell Rep. 2017; 19(9): 1739-49.

PubMed Abstract | Publisher Full Text | Free Full Text

69. Re DB, Le Verche V, Yu C, et al.: Necroptosis drives motor neuron death in models of both sporadic and familial ALS. Neuron. 2014; 81(5): 1001-8. PubMed Abstract | Publisher Full Text | Free Full Text

70. Khalid SI, Ampie L, Kelly R, et al:: Immune Modulation in the Treatment of Amyotrophic Lateral Sclerosis: A Review of Clinical Trials. Front Neurol. 2017; 8. 486 .

PubMed Abstract | Publisher Full Text | Free Full Text

71. Geloso MC, Corvino V, Marchese E, et al:: The Dual Role of Microglia in ALS: Mechanisms and Therapeutic Approaches. Front Aging Neurosci. 2017; 9: 242. PubMed Abstract | Publisher Full Text | Free Full Text

72. Orihuela R, McPherson CA, Harry GJ: Microglial M1/M2 polarization and metabolic states. Br J Pharmacol. 2016; 173(4): 649-65. PubMed Abstract | Publisher Full Text | Free Full Text

73. CKeren-Shaul H, Spinrad A, Weiner A, et al:: A Unique Microglia Type Associated with Restricting Development of Alzheimer's Disease. Cell. 2017; 169(7): 1276-1290.e17.

PubMed Abstract | Publisher Full Text | Faculty Opinions Recommendation

74. Trias E, Ibarburu S, Barreto-Núñez R, et al:: Post-paralysis tyrosine kinase inhibition with masitinib abrogates neuroinflammation and slows disease progression in inherited amyotrophic lateral sclerosis. $J$ Neuroinflammation. 2016; 13(1): 177

PubMed Abstract | Publisher Full Text | Free Full Text

75. Mora JS, Genge A, Chio A, et al:: Masitinib as an add-on therapy to riluzole in patients with amyotrophic lateral sclerosis: a randomized clinical trial. Amyotroph Lateral Scler Frontotemporal Degener. 2020; 21(1-2): 5-14. PubMed Abstract | Publisher Full Text | Faculty Opinions Recommendation

76. Brooks B, Bravver EK, Sanjak M, et al:: Ibudilast - Phosphodiesterase Type 4 Inhibitor - Bi-Modal Therapy with Riluzole in Early [ Not Requiring NonInvasive Ventilation ( NIV ) ] Cohort ( EC) and Advanced [Requiring NIV ] ( ANC) Amyotrophic Lateral Sclerosis ( ALS ) Patients - Single-Center Adaptive Design Six-Month Double-Blind ( DB ) - Placebo-Controlled Phase 1b/2a Epoch Followed by Six-Month Open Label Extension ( OLE ) Epoch, Washout (WO ) and Post-Washout Epoch ( PWO ) - Final Report and Future Directions (P6.465). Neurology. 2018; 90(15 Supplement): P6.465. Reference Source

77. Chen $\mathrm{Y}$, Wang $\mathrm{H}$, Ying $\mathrm{Z}$, et al:: Ibudilast enhances the clearance of SOD1 and TDP-43 aggregates through TFEB-mediated autophagy and lysosomal biogenesis: The new molecular mechanism of ibudilast and its implication for neuroprotective therapy. Biochem Biophys Res Commun. 2020; 526(1): 231-8. PubMed Abstract | Publisher Full Text

78. Zhang $\mathrm{H}, \mathrm{Li} \mathrm{Y}, \mathrm{Yu}$ J, et al.: Rho kinase inhibitor fasudil regulates microglia polarization and function. Neuroimmunomodulation. 2013; 20(6): 313-22. PubMed Abstract | Publisher Full Text

79. Tönges L, Günther R, Suhr M, et al.: Rho kinase inhibition modulates microglia activation and improves survival in a model of amyotrophic lateral sclerosis. Glia. 2014: 62(2): 217-32.

PubMed Abstract | Publisher Full Text

80. Takata $\mathrm{M}$, Tanaka H, Kimura M, et al.: Fasudil, a rho kinase inhibitor, limits motor neuron loss in experimental models of amyotrophic lateral sclerosis. Br J Pharmacol. 2013; 170(2): 341-51. PubMed Abstract | Publisher Full Text | Free Full Text

81. Lingor P, Weber M, Camu W, et al:: ROCK-ALS: Protocol for a Randomized, Placebo-Controlled, Double-Blind Phase Ila Trial of Safety, Tolerability and Efficacy of the Rho Kinase (ROCK) Inhibitor Fasudil in Amyotrophic Lateral Sclerosis. Front Neurol. 2019; 10: 293. PubMed Abstract | Publisher Full Text | Free Full Text

82. Koch JC, Kuttler J, Maass F, et al.: Compassionate Use of the ROCK Inhibitor Fasudil in Three Patients With Amyotrophic Lateral Sclerosis. Front Neurol. 2020; 11: 173 .

PubMed Abstract | Publisher Full Text | Free Full Text

Faculty Opinions Recommendation
83. Parker SE, Hanton AM, Stefanou SN, et al: Revisiting the role of the innate immune complement system in ALS. Neurobiol Dis. 2019; 127: 223-32. PubMed Abstract | Publisher Full Text

84. Kjældgaard AL, Pilely K, Olsen KS, et al:: Amyotrophic lateral sclerosis: The complement and inflammatory hypothesis. Mol Immunol. 2018; 102: 14-25. PubMed Abstract | Publisher Full Text

85. Lee JD, Kumar V, Fung JNT, et al.: Pharmacological inhibition of complement C5a-C5a1 receptor signalling ameliorates disease pathology in the hSOD1G93A mouse model of amyotrophic lateral sclerosis. $\mathrm{Br} J$ Pharmacol. 2017; 174(8): 689-99.

PubMed Abstract | Publisher Full Text | Free Full Text

86. Woodruff TM, Costantini KJ, Crane JW, et al.: The complement factor C5a contributes to pathology in a rat model of amyotrophic lateral sclerosis. $J$ Immunol. 2008; 181(12): 8727-34.

PubMed Abstract | Publisher Full Text

87. Fiala M, Mizwicki MT, Weitzman R, et al.: Tocilizumab infusion therapy normalizes inflammation in sporadic ALS patients. Am J Neurodegener Dis. 2013; 2(2): 129-39. PubMed Abstract | Free Full Text

88. Maier A, Deigendesch N, Müller K, et al.: Interleukin-1 Antagonist Anakinra in Amyotrophic Lateral Sclerosis--A Pilot Study. PLoS One. 2015; 10(10): e0139684.

PubMed Abstract | Publisher Full Text | Free Full Text

89. S Shin J, Kim HJ, Jeon B: Immunotherapy Targeting Neurodegenerative Proteinopathies: A-Synucleinopathies and Tauopathies. J Mov Disord. 2020; 13(1): 11-9.

PubMed Abstract | Publisher Full Text | Free Full Text | Faculty Opinions Recommendation

90. Gallardo G, Holtzman DM: Antibody Therapeutics Targeting $\mathbf{A} \boldsymbol{\beta}$ and Tau. Cold Spring Harb Perspect Med. 2017; 7(10): a024331.

PubMed Abstract | Publisher Full Text | Free Full Text

91. Urushitani M, Ezzi SA, Julien JP: Therapeutic effects of immunization with mutant superoxide dismutase in mice models of amyotrophic lateral sclerosis. Proc Natl Acad Sci U S A. 2007; 104(7): 2495-500. PubMed Abstract | Publisher Full Text | Free Full Text

92. Liu HN, Tjostheim S, Dasilva K, et al:: Targeting of monomer/misfolded SOD1 as a therapeutic strategy for amyotrophic lateral sclerosis. J Neurosci. 2012 32(26): 8791-9.

PubMed Abstract | Publisher Full Text | Free Full Text

93. Zhao B, Marciniuk K, Gibbs E, et al.: Therapeutic vaccines for amyotrophic lateral sclerosis directed against disease specific epitopes of superoxide dismutase 1. Vaccine. 2019; 37(35): 4920-7.

PubMed Abstract | Publisher Full Text | Faculty Opinions Recommendation

94. Takeuchi S, Fujiwara N, Ido A, et al:: Induction of protective immunity by vaccination with wild-type apo superoxide dismutase 1 in mutant SOD1 transgenic mice. J Neuropathol Exp Neurol. 2010; 69(10): 1044-56. PubMed Abstract | Publisher Full Text

95. Sábado J, Casanovas A, Rodrigo H, et al.: Adverse effects of a SOD1-peptide immunotherapy on SOD1 ${ }^{\mathrm{G} 93 \mathrm{~A}}$ mouse slow model of amyotrophic lateral sclerosis. Neuroscience. 2015; 310: 38-50. PubMed Abstract | Publisher Full Text

96. C Gros-Louis F, Soucy G, Larivière R, et al:: Intracerebroventricular infusion of monoclonal antibody or its derived Fab fragment against misfolded forms of SOD1 mutant delays mortality in a mouse model of ALS. J Neurochem. 2010; 113(5): 1188-99.

PubMed Abstract | Publisher Full Text | Faculty Opinions Recommendation

97. Maier M, Welt T, Wirth F, et al.: A human-derived antibody targets misfolded SOD1 and ameliorates motor symptoms in mouse models of amyotrophic lateral sclerosis. Sci Transl Med. 2018; 10(470): eaah3924. PubMed Abstract | Publisher Full Text | Faculty Opinions Recommendation

98. D Dong QX, Zhu J, Liu SY, et al:: An oligomer-specific antibody improved motor function and attenuated neuropathology in the SOD1-G93A transgenic mouse model of ALS. Int Immunopharmacol. 2018; 65: 413-21. PubMed Abstract | Publisher Full Text | Faculty Opinions Recommendation

99. Zhou Q, Lehmer C, Michaelsen M, et al.: Antibodies inhibit transmission and aggregation of C9orf72 poly-GA dipeptide repeat proteins. EMBO Mol Med. 2017; 9(5): 687-702.

PubMed Abstract | Publisher Full Text | Free Full Text

100. Nguyen L, Montrasio F, Pattamatta A, et al:: Antibody Therapy Targeting RAN Proteins Rescues C9 ALS/FTD Phenotypes in C9orf72 Mouse Model. Neuron. 2020; 105(4): 645-662.e11.

PubMed Abstract | Publisher Full Text | Free Full Text | Faculty Opinions Recommendation

101. Z Zhou Q, Mareljic N, Michaelsen M, et al: Active poly-GA vaccination prevents microglia activation and motor deficits in a C9orf72 mouse model. EMBO Mol Med. 2020; 12(2): e10919. PubMed Abstract | Publisher Full Text | Free Full Text | Faculty Opinions Recommendation

102. Tamaki Y, Shodai A, Morimura T, et al.: Elimination of TDP-43 inclusions 
linked to amyotrophic lateral sclerosis by a misfolding-specific intrabody with dual proteolytic signals. Sci Rep. 2018; 8(1): 6030. PubMed Abstract | Publisher Full Text | Free Full Text | Faculty Opinions Recommendation

103. Pozzi S, Thammisetty SS, Codron P, et al:: Virus-mediated delivery of antibody targeting TAR DNA-binding protein-43 mitigates associated neuropathology. J Clin Invest. 2019; 129(4): 1581-95. PubMed Abstract | Publisher Full Text | Free Full Text Faculty Opinions Recommendation

104. Luh LM, Bertolotti A: Potential benefit of manipulating protein quality control systems in neurodegenerative diseases. Curr Opin Neurobiol. 2020; 61 125-32.

PubMed Abstract | Publisher Full Text | Faculty Opinions Recommendation

105. Kalmar B, Lu CH, Greensmith L: The role of heat shock proteins in Amyotrophic Lateral Sclerosis: The therapeutic potential of Arimoclomol. Pharmacol Ther. 2014; 141(1): 40-54. PubMed Abstract | Publisher Full Text

106. Kieran D, Kalmar B, Dick JRT, et al:: Treatment with arimoclomol, a coinducer of heat shock proteins, delays disease progression in ALS mice. Nat Med. 2004; 10(4); 402-5.

PubMed Abstract | Publisher Full Text

107. Kalmar B, Novoselov S, Gray A, et al.: Late stage treatment with arimoclomol delays disease progression and prevents protein aggregation in the SOD1 mouse model of ALS. J Neurochem. 2008; 107(2): 339-50. PubMed Abstract | Publisher Full Text

108. Benatar M, Wuu J, Andersen PM, et al:: Randomized, double-blind, placebocontrolled trial of arimoclomol in rapidly progressive SOD1 ALS. Neurology. 2018; 90(7): e565-e574.

PubMed Abstract | Publisher Full Text | Free Full Text | Faculty Opinions Recommendation

109. Crippa V, Cicardi ME, Ramesh N, et al:: The chaperone HSPB8 reduces the accumulation of truncated TDP-43 species in cells and protects against TDP43-mediated toxicity. Hum Mol Genet. 2016; 25(18): 3908-24. PubMed Abstract | Publisher Full Text | Free Full Text

110. Crippa V, Sau D, Rusmini $P$, et al.: The small heat shock protein B8 (HspB8) promotes autophagic removal of misfolded proteins involved in amyotrophic lateral sclerosis (ALS). Hum Mol Genet. 2010; 19(7): 3440-56. PubMed Abstract | Publisher Full Text

111. Cristofani R, Crippa V, Vezzoli G, et al:: The small heat shock protein B8 (HSPB8) efficiently removes aggregating species of dipeptides produced in C9ORF72-related neurodegenerative diseases. Cell Stress Chaperones. 2018; 23(1): 1-12.

PubMed Abstract | Publisher Full Text | Free Full Text | Faculty Opinions Recommendation

112. Ganassi M, Mateju D, Bigi I, et al.: A Surveillance Function of the HSPB8-BAG3 HSP70 Chaperone Complex Ensures Stress Granule Integrity and Dynamism. Mol Cell. 2016; 63(5): 796-810. PubMed Abstract | Publisher Full Text

113. Mandrioli J, Crippa V, Cereda C, et al.: Proteostasis and ALS: Protocol for a phase II, randomised, double-blind, placebo-controlled, multicentre clinical trial for colchicine in ALS (Co-ALS). BMJ Open. 2019; 9(5): e028486. PubMed Abstract | Publisher Full Text | Free Full Text

114. Sweeny EA, Shorter J: Mechanistic and Structural Insights into the PrionDisaggregase Activity of Hsp104. J Mol Biol. 2016; 428(9 Pt B): 1870-85. PubMed Abstract | Publisher Full Text | Free Full Text

115. Shorter J, Lindquist S: Destruction or potentiation of different prions catalyzed by similar Hsp104 remodeling activities. Mol Cell. 2006; 23(3): 425-38. PubMed Abstract | Publisher Full Text | Free Full Text

116. Shorter J: Designer protein disaggregases to counter neurodegenerative disease. Curr Opin Genet Dev. 2017; 44: 1-8. PubMed Abstract | Publisher Full Text | Free Full Text

117. March ZM, Mack KL, Shorter J: AAA+ Protein-Based Technologies to Counter Neurodegenerative Disease. Biophys J. 2019; 116(8): 1380-5. PubMed Abstract | Publisher Full Text | Free Full Text

118. N Jackrel ME, DeSantis ME, Martinez BA, et al:: Potentiated Hsp104 variants antagonize diverse proteotoxic misfolding events. Cell. 2014; 156(1-2): 170-82. PubMed Abstract | Publisher Full Text | Free Full Text | Faculty Opinions Recommendation

119. - Tariq A, Lin J, Jackrel ME, et al.: Mining Disaggregase Sequence Space to Safely Counter TDP-43, FUS and a-Synuclein Proteotoxicity. Cell Rep. 2019; 28(8): 2080-2095.e6. PubMed Abstract | Publisher Full Text | Free Full Text Faculty Opinions Recommendation

120. Jackrel ME, Shorter J: Potentiated Hsp104 variants suppress toxicity of diverse neurodegenerative disease-linked proteins. Dis Model Mech. 2014; 7(10): $1175-84$.

PubMled Abstract | Publisher Full Text | Free Full Text

121. Yasuda K, Clatterbuck-Soper SF, Jackrel ME, et al: FUS inclusions disrupt RNA localization by sequestering kinesin-1 and inhibiting microtubule detyrosination. J Cell Biol. 2017; 216(4): 1015-34. PubMed Abstract | Publisher Full Text | Free Full Text
122. Djajadikerta A, Keshri S, Pavel M, et al:: Autophagy Induction as a Therapeutic Strategy for Neurodegenerative Diseases. J Mol Biol. 2020; 432(8): 2799-821.

PubMed Abstract | Publisher Full Text | Faculty Opinions Recommendation

123. Barmada SJ, Serio A, Arjun A, et al:: Autophagy induction enhances TDP43 turnover and survival in neuronal ALS models. Nat Chem Biol. 2014; 10(8): 677-85.

PubMed Abstract | Publisher Full Text | Free Full Text

124. Xia $\mathrm{Q}$, Wang $\mathrm{H}, \mathrm{Hao} \mathrm{Z}$, et al:: TDP-43 loss of function increases TFEB activity and blocks autophagosome-lysosome fusion. EMBO J. 2016; 35(2): 121-42. PubMed Abstract | Publisher Full Text | Free Full Text

125. Zhang $\mathrm{X}$, Li L, Chen S, et al.: Rapamycin treatment augments motor neuron degeneration in SOD1 1933 mouse model of amyotrophic lateral sclerosis. Autophagy. 2011; 7(4): 412-25. PubMed Abstract | Publisher Full Text

126. Zhang X, Chen S, Lu K, et al.: Verapamil Ameliorates Motor Neuron Degeneration and Improves Lifespan in the SOD1 ${ }^{\mathrm{G} 93 \mathrm{~A}}$ Mouse Model of ALS by Enhancing Autophagic Flux. Aging Dis. 2019; 10(6): 1159-73. PubMed Abstract | Publisher Full Text | Free Full Text

127. Li Y, Guo Y, Wang X, et al:: Trehalose decreases mutant SOD1 expression and alleviates motor deficiency in early but not end-stage amyotrophic latera sclerosis in a SOD1-G93A mouse model. Neuroscience. 2015; 298: 12-25. PubMed Abstract | Publisher Full Text

128. Staats KA, Hernandez $\mathrm{S}$, Schönefeldt $\mathrm{S}$, et al:: Rapamycin increases survival in ALS mice lacking mature lymphocytes. Mol Neurodegener. 2013; 8: 31. PubMed Abstract | Publisher Full Text | Free Full Text

129. N Kato M, Han TW, Xie S, et al:: Cell-free formation of RNA granules: Low complexity sequence domains form dynamic fibers within hydrogels. Cell. 2012; 149(4): 753-67.

PubMed Abstract | Publisher Full Text | Free Full Text | Faculty Opinions Recommendation

130. Molliex A, Temirov J, Lee J, et al.: Phase separation by low complexity domain promotes stress granule assembly and drives pathological fibrillization. Cell. 2015; 163(1): 123-33.

PubMed Abstract | Publisher Full Text | Free Full Text

131. L Lin Y, Protter DSW, Rosen MK, et al.: Formation and Maturation of PhaseSeparated Liquid Droplets by RNA-Binding Proteins. Mol Cell. 2015; 60(2): 208-19.

PubMed Abstract | Publisher Full Text | Free Full Text | Faculty Opinions Recommendation

132. P Patel A, Lee HO, Jawerth L, et al:: A Liquid-to-Solid Phase Transition of the ALS Protein FUS Accelerated by Disease Mutation. Cell. 2015; 162(5): 1066-77. PubMed Abstract | Publisher Full Text | Faculty Opinions Recommendation

133. Gasset-Rosa F, Lu S, Yu H, et al:: Cytoplasmic TDP-43 De-mixing Independent of Stress Granules Drives Inhibition of Nuclear Import, Loss of Nuclear TDP43, and Cell Death. Neuron. 2019; 102(2): 339-357.e7. PubMed Abstract | Publisher Full Text | Free Full Text

134. C Mann JR, Gleixner AM, Mauna JC, et al.: RNA Binding Antagonizes Neurotoxic Phase Transitions of TDP-43. Neuron. 2019; 102(2): 321-338.e8. PubMed Abstract | Publisher Full Text | Free Full Text | Faculty Opinions Recommendation

135. Boyd JD, Lee P, Feiler MS, et al.: A high-content screen identifies novel compounds that inhibit stress-induced TDP-43 cellular aggregation and associated cytotoxicity. J Biomol Screen. 2014; 19(1): 44-56. PubMed Abstract | Publisher Full Text | Free Full Text

136. Parker SJ, Meyerowitz J, James JL, et al:: Inhibition of TDP-43 accumulation by bis(thiosemicarbazonato)-copper complexes. PLoS One. 2012; 7(8): e42277. PubMed Abstract | Publisher Full Text | Free Full Text

137. Prasad A, Raju G, Sivalingam V, et al:: An acridine derivative, 4,5-bis $\{(\mathrm{N}-$ carboxy methyl imidazolium)methyl\}acridine dibromide, shows anti-TDP-43 aggregation effect in ALS disease models. Sci Rep. 2016; 6: 39490. PubMed Abstract | Publisher Full Text | Free Full Text

138. Fang MY, Markmiller S, Vu AQ, et al:: Small-Molecule Modulation of TDP-43 Recruitment to Stress Granules Prevents Persistent TDP-43 Accumulation in ALS/FTD. Neuron. 2019; 103(5): 802-819.e11. PubMed Abstract | Publisher Full Text | Free Full Text | Faculty Opinions Recommendation

139. - McGurk L, Gomes E, Guo L, et al.: Poly(ADP-Ribose) Prevents Pathological Phase Separation of TDP-43 by Promoting Liquid Demixing and Stress Granule Localization. Mol Cell. 2018; 71(5): 703-717.e9. PubMed Abstract | Publisher Full Text | Free Full Text | Faculty Opinions Recommendation

140. Duan Y, Du A, Gu J, et al:: PARylation regulates stress granule dynamics, phase separation, and neurotoxicity of disease-related RNA-binding proteins. Cell Res. 2019; 29(3): 233-47. PubMed Abstract | Publisher Full Text | Free Full Text | Faculty Opinions Recommendation

141. McGurk L, Mojsilovic-Petrovic J, van Deerlin VM, et al:: Nuclear poly(ADPribose) activity is a therapeutic target in amyotrophic lateral sclerosis. Acta 
Neuropathol Commun 2018; 6(1): 84 PubMed Abstract | Publisher Full Text | Free Full Text

142. McGurk L, Rifai OM, Bonini NM: Poly(ADP-Ribosylation) in Age-Related Neurological Disease. Trends Genet. 2019; 35(8): 601-13. PubMed Abstract | Publisher Full Text | Free Full Text

143. Hofweber M, Hutten S, Bourgeois B, et al:: Phase Separation of FUS Is Suppressed by Its Nuclear Import Receptor and Arginine Methylation. Cell. 2018; 173(3): 706-719.e13.

PubMed Abstract | Publisher Full Text | Faculty Opinions Recommendation

144. Q Qamar S, Wang G, Randle SJ, et al:: FUS Phase Separation Is Modulated by a Molecular Chaperone and Methylation of Arginine Cation-m Interactions. Cell. 2018; 173(3): 720-734.e15.

PubMed Abstract | Publisher Full Text | Free Full Text Faculty Opinions Recommendation

145. Fujii S, Takanashi K, Kitajo K, et al:: Treatment with a Global Methyltransferase Inhibitor Induces the Intranuclear Aggregation of ALS-Linked FUS Mutant In Vitro. Neurochem Res. 2016; 41(4): 826-35. PubMed Abstract | Publisher Full Text

146. Moore S, Rabichow BE, Sattler R: The Hitchhiker's Guide to Nucleocytoplasmic Trafficking in Neurodegeneration. Neurochem Res. 2020; 45(6): 1306-27. PubMed Abstract | Publisher Full Text

147. Barmada SJ, Skibinski G, Korb E, et al:: Cytoplasmic mislocalization of TDP43 is toxic to neurons and enhanced by a mutation associated with familial amyotrophic lateral sclerosis. J Neurosci. 2010; 30(2): 639-49. PubMed Abstract | Publisher Full Text | Free Full Text

148. Walker AK, Spiller KJ, Ge G, et al.: Functional recovery in new mouse models of ALS/FTLD after clearance of pathological cytoplasmic TDP-43. Acta Neuropathol. 2015; 130(5): 643-60 PubMed Abstract | Publisher Full Text | Free Full Text

149. Ishigaki S, Sobue G: Importance of Functional Loss of FUS in FTLD/ALS. Front Mol Biosci. 2018; 5: 44. PubMed Abstract | Publisher Full Text | Free Full Text

150. Archbold HC, Jackson KL, Arora A, et al: TDP43 nuclear export and neurodegeneration in models of amyotrophic lateral sclerosis and frontotemporal dementia. Sci Rep. 2018; 8(1): 4606. PubMed Abstract | Publisher Full Text | Free Full Text

151. Chou CC, Zhang Y, Umoh ME, et al:: TDP-43 pathology disrupts nuclear pore complexes and nucleocytoplasmic transport in ALS/FTD. Nat Neurosci. 2018; 21(2): 228-39. PubMed Abstract | Publisher Full Text | Free Full Text

152. Steyaert J, Scheveneels $\mathrm{W}$, Vanneste $\mathrm{J}$, et al.: FUS-induced neurotoxicity in Drosophila is prevented by downregulating nucleocytoplasmic transport proteins. Hum Mol Genet. 2018; 27(23): 4103-16. PubMed Abstract | Publisher Full Text | Free Full Text

153. Ederle H, Funk $\mathrm{C}$, Abou-Ajram $\mathrm{C}$, et al:: Nuclear egress of TDP-43 and FUS occurs independently of Exportin-1/CRM1. Sci Rep. 2018; 8(1): 7084 PubMed Abstract | Publisher Full Text | Free Full Text

154. Pinarbasi ES, Cağatay T, Fung HYJ, et al.: Active nuclear import and passive nuclear export are the primary determinants of TDP-43 localization. Sci Rep. 2018; 8(1): 7083

PubMed Abstract | Publisher Full Text | Free Full Text

155. C Guo L, Kim HJ, Wang H, et al:: Nuclear-Import Receptors Reverse Aberrant Phase Transitions of RNA-Binding Proteins with Prion-like Domains. Cell. 2018; 173(3): 677-692.e20 PubMed Abstract | Publisher Full Text | Free Full Text | Faculty Opinions Recommendation

156. Yoshizawa T, Ali R, Jiou J, et al.: Nuclear Import Receptor Inhibits Phase Separation of FUS through Binding to Multiple Sites. Cell. 2018; 173(3): 693-705.e22.

PubMed Abstract | Publisher Full Text | Free Full Text | Faculty Opinions Recommendation

157. Niaki AG, Sarkar J, Cai X, et al.: Loss of Dynamic RNA Interaction and Aberrant Phase Separation Induced by Two Distinct Types of ALS/FTD-Linked FUS Mutations. Mol Cell. 2020; 77(1): 82-94.e4 PubMed Abstract | Publisher Full Text | Free Full Text | Faculty Opinions Recommendation

158. Saville BR, Berry SM: Efficiencies of platform clinical trials: A vision of the future. Clin Trials. 2016; 13(3): 358-66. PubMed Abstract | Publisher Full Text

159. Zhou X, Liu S, Kim ES, et al.: Bayesian adaptive design for targeted therapy development in lung cancer--a step toward personalized medicine. Clinical Trials. 2008; 5(3): 181-93.

PubMed Abstract | Publisher Full Text | Free Full Text

160. Lopez-Chavez A, Thomas A, Rajan A, et al:: Molecular profiling and targeted therapy for advanced thoracic malignancies: a biomarker-derived, multiarm, multihistology phase II basket trial. J Clin Oncol. 2015; 33(9): 1000-7. PubMed Abstract | Publisher Full Text | Free Full Text

161. Steuer CE, Papadimitrakopoulou V, Herbst RS, et al: Innovative Clinical Trials: The LUNG-MAP Study. Clin Pharmacol Ther. 2015; 97(5): 488-91. PubMed Abstract | Publisher Full Text

162. Hirakawa A, Asano J, Sato $\mathrm{H}$, et al.: Master protocol trials in oncology: Review and new trial designs. Contemp Clin Trials Commun. 2018; 12: 1-8. PubMed Abstract | Publisher Full Text | Free Full Text

163. Healy Center for ALS: HEALEY ALS Platform Trial. 2020 [cited 202018 May]. Reference Source 